\title{
Molecular data for Crenavolva species (Gastropoda, Ovulidae) reveals the synonymy of $C$. chiapponii
}

\author{
Bastian T. Reijnen' \\ I Department of Marine Zoology, Naturalis Biodiversity Center, P.O. Box 9517, 2300 RA Leiden, The Netherlands \\ Corresponding author: Bastian T. Reijnen (Bastian.Reijnen@naturalis.nl)
}

Academic editor: T. Backeljau | Received 16 December 2014 | Accepted 13 April 2015 | Published 30 April 2015

http://zoobank.org/4C35416C-73F6-4E97-8394-44D5115FFFDD

Citation: Reijnen BT (2015) Molecular data for Crenavolva species (Gastropoda, Ovulidae) reveals the synonymy of $C$. chiapponii. ZooKeys 501: 15-26. doi: 10.3897/zookeys.501.9144

\begin{abstract}
During fieldwork in Indonesia and Malaysia, eight lots containing 33 specimens belonging to the genus Crenavolva (Ovulidae) were collected. Species were initially identified as C. aureola, C. chiapponii, C. striatula and C. trailli, respectively. For C. chiapponii this is the second record. In contrast to the ecological data available from the original description of this species, it was found in shallow water on a gorgonian host coral, i.e. Acanthogorgia sp. A molecular analysis based on COI and 165 mtDNA markers, including sequence data obtained from GenBank, showed that $C$. chiapponii should be considered a junior synonym of $C$. aureola and that previously identified ovulid specimens are probably misidentified.
\end{abstract}

\section{Keywords}

Acanthogorgia, host association, molecular phylogeny, Octocorallia, 16S, COI

\section{Introduction}

The nominal taxon Crenavolva was introduced as a subgenus by Cate (1973), together with the subgenera Crenavolva, Cuspivolva and Serratovolva. In the most recent overview regarding Ovulidae these three taxa are considered genera (Lorenz and Fehse 2009). At present 18 nominal species are recognized within Crenavolva (Rosenberg 2014), most of which are considered rare (Lorenz and Fehse 2009). These species are 
considered rare because few specimens have been collected, probably because they occur at depths greater than standard recreational diving depth of c. $30 \mathrm{~m}$ and/or are only known from a limited geographical area, usually just the type locality. This also accounts for C. chiapponii Lorenz \& Fehse, 2009, which is only known from Balicasag Isl., Bohol, Philippines, where specimens were trawled from 70-120 m depth and, therefore, were considered rare and confined to deeper water (Lorenz and Fehse 2009). Like almost all other ovulids, species of Crenavolva are associated with octocoral hosts (Schiaparelli et al. 2005; Reijnen 2010) belonging to several families (e.g. Melithaeidae, Ellisellidae, Subergorgiidae and Plexauridae). However, the host species are usually not collected or are disregarded and therefore unknown, which is also the case for C. chiapponii.

Molecular data (16S and COI) obtained from Crenavolva was used by Meyer (2003) to root the phylogeny of the Cypraeidae. Later, the 16S sequence data were used by Schiaparelli et al. (2005) to produce the first molecular phylogenetic reconstruction of the Ovulidae, which included two Crenavolva species: C. cf. rosewateri (Cate, 1973) and C. tokuoi Azuma, 1989. In the present study, material of four additional nominal Crenavolva species, amongst other ovulids, have been used to reconstruct a phylogeny. The newly acquired molecular data are for $C$. aureola (Fehse, 2002), C. chiapponii Lorenz \& Fehse, 2009, C. striatula (Sowerby I, 1828) (type species), and C. trailli (Adams, 1855). In addition to this phylogenetic reconstruction, data on host species and distributional records are given for this group of rarely recorded ovulid snails.

\section{Materials and methods}

\section{Collection and identification}

During fieldwork in Indonesia (Halmahera, Ternate; Sulawesi, Lembeh Strait) and Malaysia (Borneo, Semporna and Kudat) specimens of Crenavolva species were collected by SCUBA diving (Table 1). The snails and their octocoral hosts were photographed in situ (Fig. 1) whenever possible and subsequently fixed in $80 \%$ ethanol. The holotype of C. chiapponii was studied at the Muséum national d'Histoire naturelle $(\mathrm{MNHN})$ in Paris. For the identification of the other ovulid species, Cate (1973), Fehse (2002b) and Lorenz and Fehse (2009) were used. For the identification of the host species, microscopy slides of their calcareous skeletal parts (sclerites) were made by dissolving the samples in a $4 \%$ solution of household bleach. The residual sclerites were rinsed with tap water followed by demineralised water before mounting on a slide or on a stub for Scanning Electron Microscopy (SEM). Stubs with sclerites were coated with $\mathrm{Au} / \mathrm{Pd}$ before SEM images were made with a JEOL $6480 \mathrm{LV}$. Identification of the octocorals to genus level was based on Stiasny (1947) and Fabricius and Alderslade (2001). 


\begin{tabular}{|c|c|c|c|c|c|c|c|c|c|c|c|c|c|}
\hline 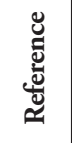 & F & 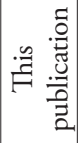 & F. & 尝 & 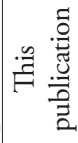 & 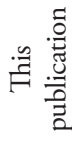 & 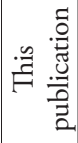 & 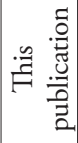 & F. & 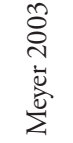 & 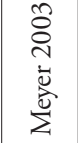 & 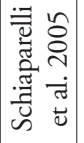 & 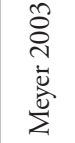 \\
\hline 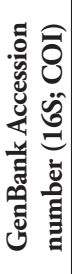 & 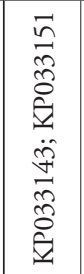 & 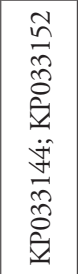 & 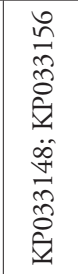 & $\begin{array}{l}\hat{n} \\
\hat{\approx} \\
\hat{\delta} \\
\hat{\sigma}\end{array}$ & 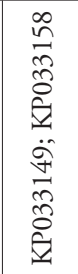 & 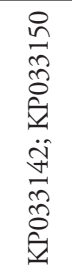 & 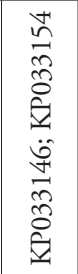 & 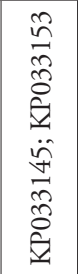 & 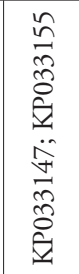 & 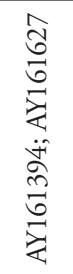 & 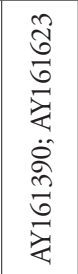 & \begin{tabular}{l}
$\dot{1}$ \\
$\hat{\tilde{n}}$ \\
$\hat{\delta}$ \\
$\infty$ \\
$\infty$ \\
\multirow{2}{*}{}
\end{tabular} & 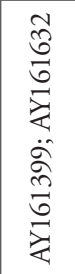 \\
\hline 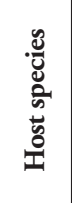 & 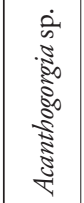 & 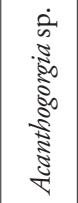 & 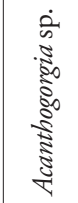 & 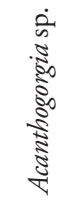 & 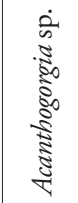 & 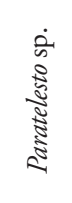 & 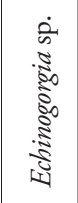 & 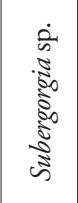 & $\begin{array}{l}\dot{0} \\
\text { के } \\
\text { हैँ } \\
\text { हूँ } \\
\text { है } \\
\text { हू }\end{array}$ & ' & I & ' & \\
\hline 气̊ & 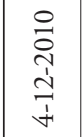 & 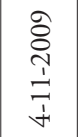 & 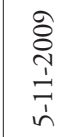 & $\begin{array}{l}\stackrel{8}{0} \\
\stackrel{1}{1} \\
\stackrel{1}{1}\end{array}$ & 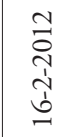 & $\begin{array}{l}\stackrel{0}{a} \\
\stackrel{1}{1} \\
\text { İ } \\
\text { à }\end{array}$ & 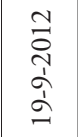 & 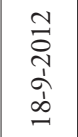 & 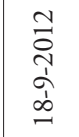 & ' & ' & I & 1 \\
\hline 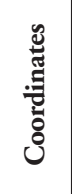 & 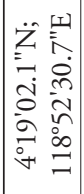 & 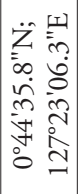 & 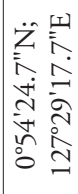 & 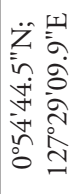 & 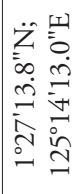 & 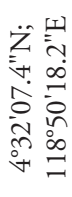 & 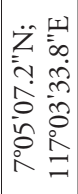 & 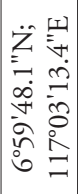 & 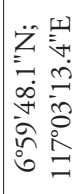 & ' & ' & ' & 1 \\
\hline 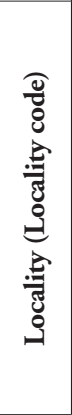 & 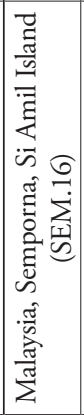 & 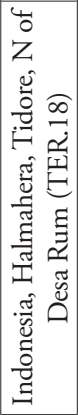 & 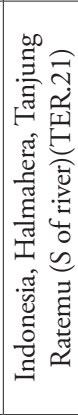 & 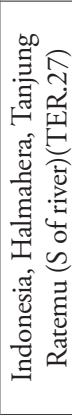 & 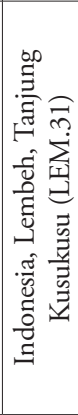 & 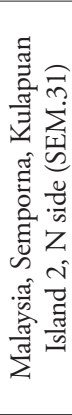 & 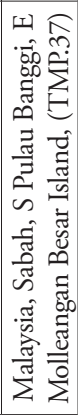 & 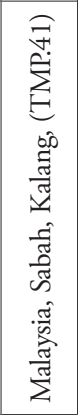 & 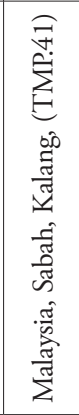 & 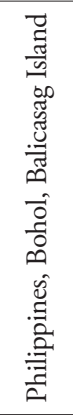 & 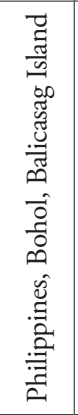 & 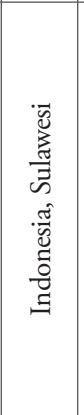 & 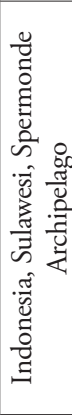 \\
\hline $\begin{array}{l}\text { ֻूँ } \\
\text { के }\end{array}$ & 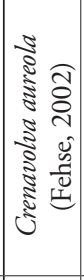 & 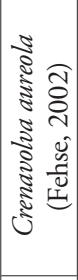 & 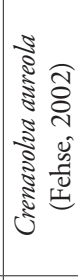 & 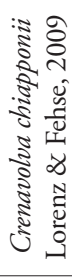 & 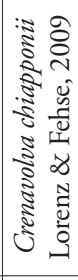 & 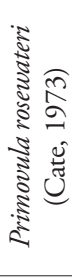 & 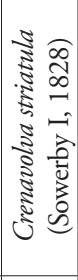 & 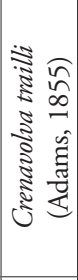 & 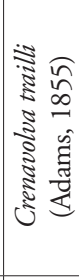 & 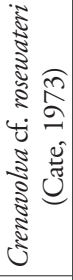 & 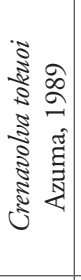 & 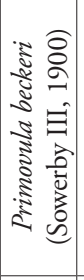 & 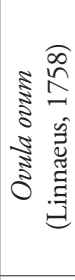 \\
\hline 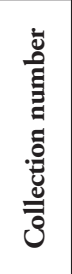 & 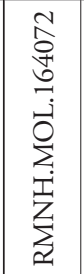 & 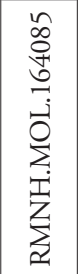 & 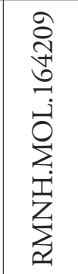 & 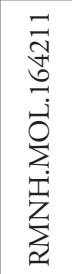 & 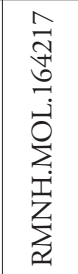 & 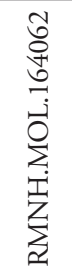 & 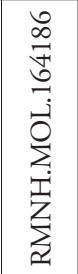 & 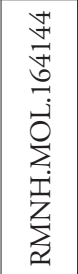 & 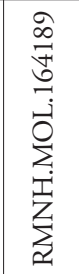 & I & ' & ' & \\
\hline
\end{tabular}




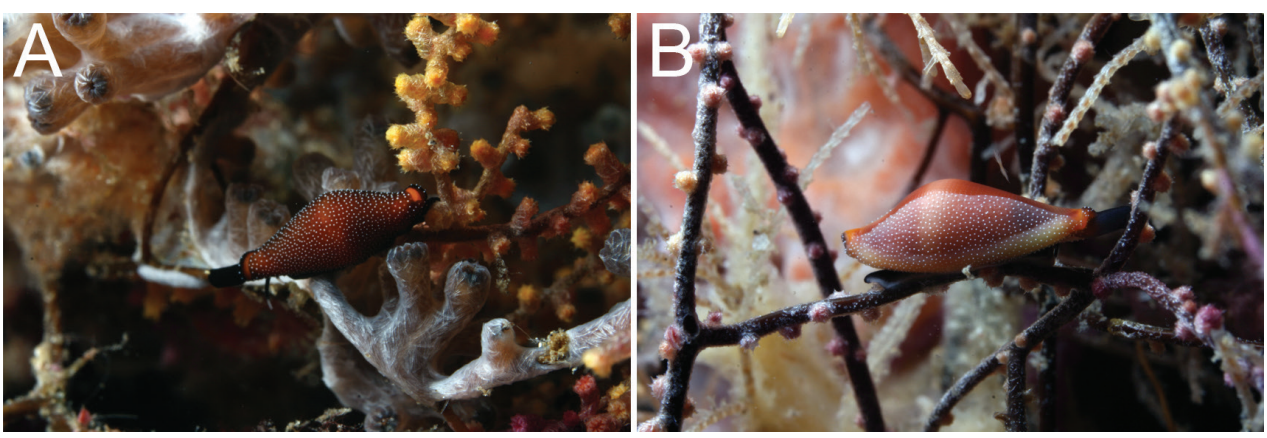

Figure I. A In situ image of Crenavolva aureola (Fehse, 2002) (RMNH.MOL.164209) and B C. chiapponii Lorenz \& Fehse, 2009 (RMNH.MOL.164211) on Acanthogorgia sp. at Halmahera, Indonesia at $21 \mathrm{~m}$ and $17 \mathrm{~m}$ depth respectively.

\section{Barcoding Ovulidae}

Specimens were barcoded for the COI barcoding region and for additional phylogenetic research also for the $16 \mathrm{~S}$ marker. Tissue samples obtained from the foot and/or mantle were extracted with the Machery-Nagel DNA extraction kit on a KingFisher Flex. The standard COI barcoding primers by Folmer et al. (1994) and the Palumbi (1996) $16 S$ primers were used. PCR amplification was performed on a C1000 Touch Thermal Cycler (Bio-RAD). Sequencing of the PCR products was performed at Macrogen Europe on an ABI 3730xl Automated Sequencer. Sequences were edited in Sequencher 4.10.1 and aligned with GUIDANCE (Penn et al. 2010) using the MAFFT algorithm (Katoh et al. 2005). Selecting an evolutionary model was done with jModeltest based on the Akaike Information Criterion score. MEGA 6.0.6 (Tamura et al. 2013) was used to perform Maximum Likelihood (ML) and Maximum Parsimony (MP) analyses and to calculate p-distances. Bayesian analyses were performed in MrBayes 3.2.0 (Ronquist and Huelsenbeck 2003). MrBayes was run for 4,000,000 generations with six chains. Data were sampled every 100 generations. Sequence data for Ovula ovum (Linnaeus, 1758) from GenBank was used as an outgroup. GenBank data for Crenavolva cf. rosewateri (Cate, 1973), C. tokuoi Azuma, 1989 and Primovula beckeri (Sowerby III, 1900) was also included in the phylogenetic analyses.

\section{Results}

\section{Collecting and morphology}

Eight lots, containing 33 specimens representing four nominal Crenavolva species ( $C$. aureola, C. chiapponii, C. striatula and C. trailli) were collected in Indonesia and Malaysia (Table 1; Fig. 2). For C. chiapponii this is the first record from shallow water. The specimens were assigned to these nominal species based on shell shape (rhomboid, inflated or slender) and the colour bands on the dorsum, which in case of $C$. striatula were 


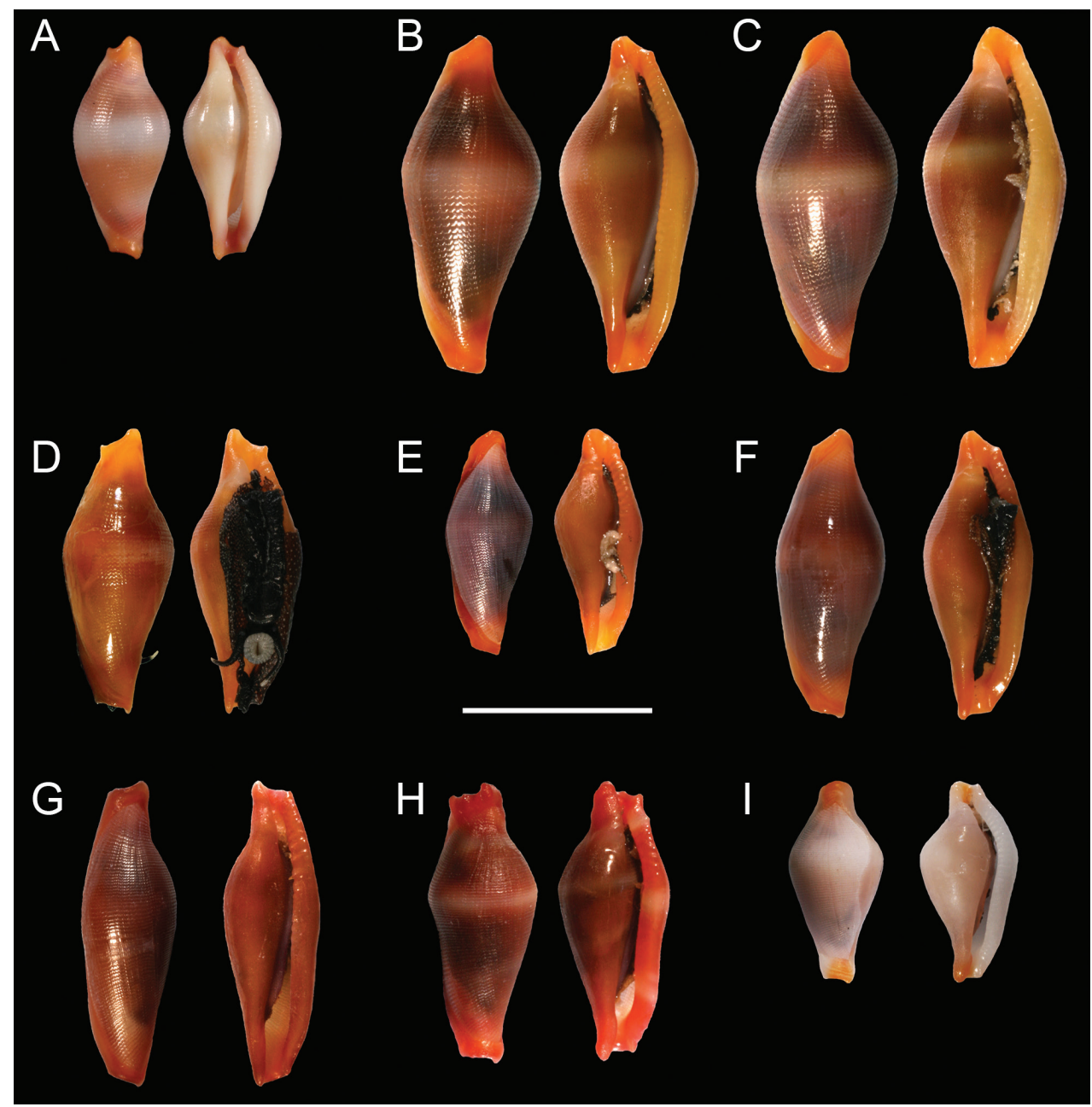

Figure 2. Dorsal and ventral views of shells. A Holotype of Crenavolva chiapponii Lorenz \& Fehse, 2009 (MNHN 21244) B C. chiapponii Lorenz \& Fehse, 2009 (RMNH.MOL.164211) C C. chiapponii Lorenz \& Fehse, 2009 (RMNH.MOL.164217) D C. aureola (Fehse, 2002) (RMNH.MOL.164085) E C. aureola (Fehse, 2002) (RMNH.MOL.164072) F C. aureola (Fehse, 2002) (RMNH.MOL.164209) G C. trailli (Adams, 1855) (RMNH.MOL.164144) H C. striatula (Sowerby I, 1828) (RMNH.MOL.164186) I Primovula rosewateri (Cate, 1973) (RMNH.MOL.164062). Scale bars: 5 mm.

also present on the labrum. For C. aureola and C. chiapponii the absence or presence of a white dorsal band on the shell is allegedly the most obvious character to distinguish the species. After examination of the illustrations presented by Lorenz and Fehse (2009) and the newly collected material, minor morphological differences (strongly or weakly pronounced dentation, keeling angle, strongly or weakly produced funiculum, position of the widest part of the shell) do not clearly separate between C. aureola and C. chiapponii and can be considered morphological variation in a single species. The soft tissue 
colouration of both $C$. aureola and $C$. chiapponii is very similar (e.g. Fig 1; Lorenz and Fehse 2009: A106, A107 p. 527). Both have a semi-transparent mantle which is entirely covered with small, irregularly placed, white dots, and both have a completely black or white foot, black tentacles with white tips, and a black siphon.

\section{Molecular data}

Nine specimens representing five species were sequenced for COI and 16S. For one sample of C. chiapponii (RMNH.MOL.164211) the $16 \mathrm{~S}$ marker could not be amplified. Sequences were concatenated and aligned (GUIDANCE alignment score: 0.965034 ) which resulted in an alignment length of 1080 base pairs per specimen including indels. Sequences obtained from GenBank are slightly shorter ( $\sim 40$ base pairs), these missing base pairs were coded as 'missing data'. The program jModeltest yielded in $\mathrm{HKY}+\mathrm{G}$ as most optimal evolutionary model. This evolutionary model was implemented in the Bayesian and ML analysis. The results from the different phylogenetic reconstructions were congruent, therefore only the ML tree is shown (Fig. 3).

In the phylogenetic reconstructions, specimens of Crenavolva striatula and $C$. tokuoi form an unresolved trichotomy with the other Crenavolva specimens. The two Primovula species cluster together and are well-supported sister species to all the Crenavolva species (with C. striatula as type species for the genus). This implies that the Crenavolva species used herein form a monophyletic group. The clustering of two C. trailli specimens is highly supported. Another well-supported clade holds three nominal species: Crenavolva aureola, $C$. chiapponii and $C$. cf. rosewateri. The pairwise p-distances between these three species are very low (16S: 0.2\%; COI: 0.7\%; concatenated: 0.9\%).

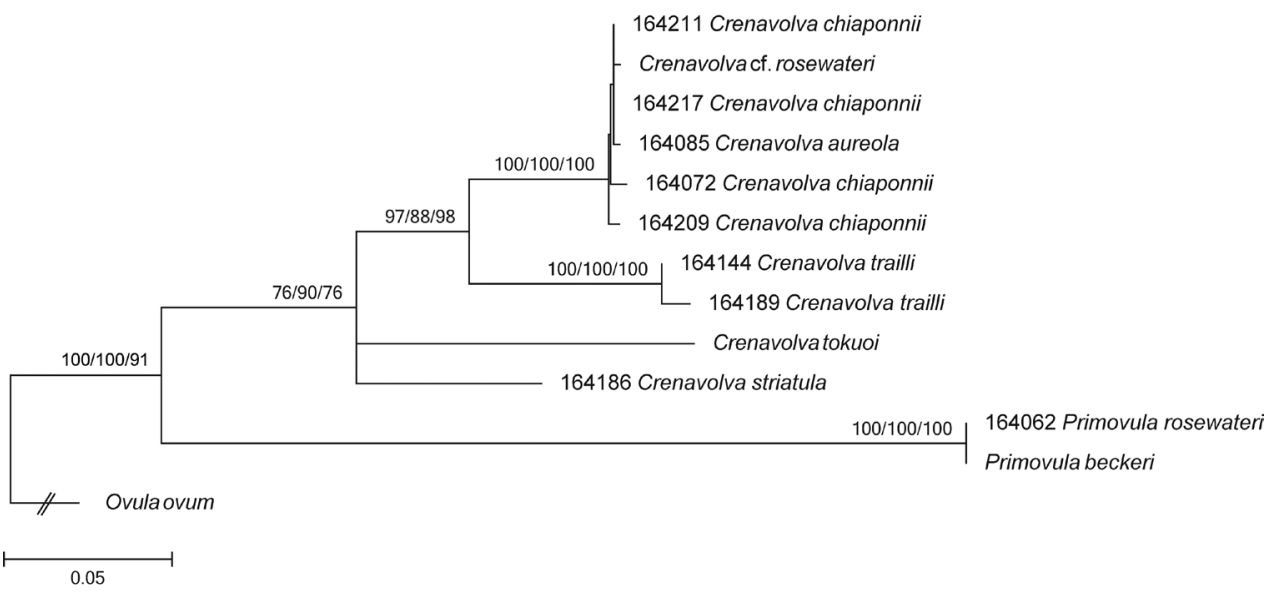

Figure 3. Maximum Likelihood cladogram with support values for the ML/MP/BP analyses. Numbers preceding the species names represent RMNH.MOL. collection numbers of Naturalis Biodiversity Center; species names without numbers are obtained from GenBank for which additional data can be found in Table 1. 
In contrast, the sequence divergence between $C$. trailli and the $C$. chiapponii / $C$. aureola clade is almost ten times larger (16S: 5.2\%; COI: 8.7\%; concatenated: 8.2\%). The sequence divergence between the two C. trailli specimens (16S: 0.6\%; COI: 0.8\%; concatenated: $0.8 \%$ ) is almost equal to that between $C$. aureola and $C$. chiapponii. With the help of the Automatic Barcode Gap Discovery tool (ABGD) (Puillandre et al. 2011), the data were analysed to identify the MOTU's within the dataset. The results of this analysis showed that the barcode gap to identify the different species is $5-6 \%$ sequence divergence. This resulted in five groups containing the following species: 1 , C. aureola, C. chiapponii, C. cf. rosewateri; 2, C. trailli; 3, C. tokuoi; 4, C. striatula; 5, P. rosewateri. One of the samples obtained from GenBank, viz. Crenavolva cf. rosewateri (= Primovula cf. rosewateri), clusters surprisingly within the clade containing C. aureola and $C$. chiapponii and not with the other Primovula rosewateri specimen. Instead, Primovula beckeri proves to be identical to the newly sequenced specimen of Primovula rosewateri from Malaysia.

\section{Octocoral hosts}

Almost all Ovulidae species are associated with Octocorallia hosts. By examining the sclerites and the habitus of the host corals, several new host species for ovulids of the genus Crenavolva could be identified. An overview of previously identified host species and new records is provided in Table 2. Some of the former host identifications were published with obsolete generic names, and therefore their names in the current literature are also provided. Before $C$. chiapponii was synonymised, Acanthogorgia would have been a new host record. Yet, Reijnen (2010) already recorded Acanthogorgia sp. as a host for $C$. aureola and therefore it is not a new host record. Morphologically at least two different species of Acanthogorgia could be distinguished but these could not be identified since a revision of the family Acanthogorgiidae is lacking.

Table 2. Literature overview of the octocoral hosts of selected Crenavolva species including new records. Updated names of the octocoral hosts are provided between parentheses.

\begin{tabular}{|c|c|c|}
\hline Ovulid species & Host genera & Reference \\
\hline Crenavolva aureola & $\begin{array}{c}\text { Euplexaura; Astromuricea (= Echinogorgia); } \\
\text { Acanthogorgia }\end{array}$ & Lorenz and Fehse 2009; Reijnen 2010 \\
\hline $\begin{array}{l}\text { Crenavolva chiapponii } \\
\qquad(=\text { C. aureola })\end{array}$ & Acanthogorgia & this publication; Reijnen 2010 \\
\hline Crenavolva striatula & Ellisella; Euplexaura; Echinogorgia & $\begin{array}{l}\text { Lorenz and Fehse 2009; Yamamoto } \\
\text { 1973; Cumming 1997; Mase 1989; }\end{array}$ \\
\hline Crenavolva trailli & $\begin{array}{c}\text { Echinogorgia; Anthoplexaura (= Astrogorgia); } \\
\text { Plexauroides (= Echinogorgia); Euplexaura; Subergorgia }\end{array}$ & Goh et al. 1999; Mase 1989 \\
\hline Primovula rosewateri & $\begin{array}{c}\text { Subergorgia; Dendronephthya; Stereonephthya; } \\
\text { Paratelesto }\end{array}$ & $\begin{array}{l}\text { Goh et al. 1999; Lorenz and Fehse } \\
\text { 2009; this publication }\end{array}$ \\
\hline Primovula beckeri & $\begin{array}{l}\text { Acanthogorgia; } \text { Acabaria }(=\text { Melithaea }) ; \text { Unicella }[\mathrm{sic}] \\
(=\text { Eunicella }) ; \text { Lophogorgia }(=\text { Leptogorgia })\end{array}$ & $\begin{array}{l}\text { Schiaparelli et al. 2005; Lorenz and } \\
\text { Fehse 2009 }\end{array}$ \\
\hline
\end{tabular}


Furthermore, examination of the ovulid species and their octocoral hosts revealed that in two instances individuals formerly identified as C. chiapponii and C. aureola would have co-occurred on the same host coral, in both cases Acanthogorgia sp.

\section{Discussion}

Based on the molecular data and morphological observations listed above, C. chiapponii is considered a junior synonym of $C$. aureola. The systematic account is therefore as follows:

\section{Systematic part}

\section{Family Ovulidae Fleming, 1822 \\ Genus Crenavolva Cate, 1973 \\ Crenavolva aureola (Fehse, 2002)}

Primovula aureola Fehse 2002: 37, pl. 1, fig. 1

Delonovolva formosa. - Gosliner et al. 1996: 136, fig. 469. Not Delonovolva formosa

(Sowerby II in Adams and Reeve 1848) [= Cuspivolva formosa (Sowerby II in Adams and Reeve 1848)]

Primovula sp. - Coleman 2003: 51, fig. (Ovul: 121).

Crenavolva chiapponii Lorenz and Fehse 2009: 69, pl. 74, fig. 7-11.

The occurrence of $C$. chiapponii ( $=C$. aureola) on Indonesian shallow water coral reefs would have represented new distribution records, both geographically and bathymetrically, before it was synonymised. However $C$. chiapponii proved to be a junior synonym of $C$. aureola and the new distribution records fall within the distribution range already known for $C$. aureola. Apparently, the dorsal white band and the minor morphological differences in shell shape are not indicative of species-level differences between C. aureola and C. chiapponii.

\section{Molecular data}

The species Primovula rosewateri was previously placed in the genus Crenavolva by Cate (1973) but Fehse (2002a) moved it to Primovula, primarily based on the triangular shape of the funiculum. The results of the molecular analyses (Fig. 3) support this decision. There is great genetic similarity between $C$. cf. rosewateri (= Primovula cf. rosewateri) obtained from GenBank, and C. aureola. However, the specimen from GenBank was collected from Balicasag Island, near Bohol, Philippines, which is the 
type locality of $C$. chiapponii. This location is approximately $85 \mathrm{~km}$ from Mactan Island of Cebu, Philippines which is the type locality of $C$. aureola. It is not unlikely that the so-called $C$. cf. rosewateri from GenBank (AY161394 (16S), AY161627 (COI)) was misidentified and actually represents $C$. aureola. Moreover, the newly sequenced specimen of $P$. rosewateri from Malaysia convincingly clusters with Primovula beckeri. According to Lorenz and Fehse 2009, P. beckeri has an E African distribution and was originally described from South Africa. The specimen obtained from GenBank is from Sulawesi, Indonesia (Schiaparelli et al. 2005). It is therefore unlikely that this sequence represents $P$. beckeri but instead is the quite similar species from the central Indo-Pacific, $P$. rosewateri.

\section{Host species and distribution records}

The ranges of the presently discussed species all fit within the Coral Triangle (see Hoeksema 2007) and depend on the ranges of their host species. Species of the genus Acanthogorgia are not unique hosts for just Crenavolva spp. Reijnen (2010) already mentioned Acanthogorgia spp. as a host for Dentiovula eizoi Cate \& Azuma, 1973 (in Cate 1973) and D. colobica (Azuma \& Cate, 1971). Acanthogorgia species and their ovulid associates are both known to occur from shallow to deep water in the Coral Triangle. In an overview of the Acanthogorgiidae by Stiasny (1947) the deepest record for an Acanthogorgia species is $4239 \mathrm{~m}$, collected SE of Seram, Indonesia (Acalycigorgia densiflora = Acanthogorgia densiflora (Kükenthal \& Gorzawsky, 1908). Nevertheless, Stiasny (1947) doubts the identification and compared it to congeneric species which are found in waters not exceeding $400 \mathrm{~m}$ depth. As a result Stiasny (1947) doubts the entire record. Therefore the deepest reliable record for an Acanthogorgia species in the Malayan Archipelago is $1254 \mathrm{~m}$ for Acanthogorgia multispina (Kükenthal \& Gorzawsky, 1908). The deepest record for Crenavolva species is from approximately $1000 \mathrm{~m}$, which is the deepest record for any ovulid species found to date (Lorenz and Fehse 2009).

\section{Acknowledgements}

Many thanks to Dr Bert W. Hoeksema who organized the Ternate and Lembeh Strait expedition together with Ir M.I. Yosephine Tuti Hermanlimianto under the umbrella of E-Win (Ekspedisi Widya Nusantara). LIPI Ternate and LIPI Bitung are acknowledged for accommodating the research at their field stations. LIPI and RISTEK granted research permits. The Semporna Marine Ecological Expedition (SMEE2010) was jointly organized by WWF-Malaysia, Universiti Malaysia Sabah's Borneo Marine Research Institute, Naturalis Biodiversity Center and Universiti Malaya's Institute of Biological Sciences, while research permission was granted by the Economic Planning Unit, Prime Minister's Department, Economic Planning Unit Sabah, Sabah Parks 
and Department of Fisheries Sabah. The MV Celebes Explorer accommodated the research in Semporna. The 2012 Tun Mustapha Park expedition (TMP) was jointly organized by WWF-Malaysia, Universiti Malaysia Sabah (UMS), Sabah Parks and Naturalis Biodiversity Center, the Netherlands. The research permits were granted by the Economic Planning Unit, Prime Minister's Department Malaysia and Sabah Biodiversity Centre. Both expeditions to Malaysia were co-organised by Ms Zarinah Waheed and WWF Malaysia, which was greatly appreciated. Dr Philippe Bouchet and Ms Virginie Heros were so kind to accommodate a visit to Muséum national d'Histoire naturelle (MNHN) in Paris to investigate the Ovulidae (type) collections. Dr Leendert P. van Ofwegen kindly provided help by identifying the octocoral hosts and Sancia van der Meij was a perfect dive buddy and ovulid hunter. Sequencing of the barcoding region of the ovulids was part of one of the barcoding initiatives within the Naturalis Biodiversity Center. Funding for fieldwork was provided by the Jan-Joost ter Pelkwijkfonds and A.M. Buitendijkfonds (Naturalis Biodiversity Center), Malacological Society of Australasia and the Percy Sladen Fund. I also would like to thank Prof Dr Catherine S. McFadden, an anonymous reviewer and Dr Thierry Backeljau for their constructive comments and remarks which improved the manuscript greatly.

\section{References}

Adams A (1855) Descriptions of twenty-five new species of shells from the collection of Hugh Cumming. Proceedings of the Zoological Society London 23: 221-226.

Adams A, Reeve LA (1848-1850) Mollusca. In: Adams A (Ed.) The zoology of the voyage of H.M.S. Samarang under the command of Sir Edward Belcher, during the years 18431846. Reeve and Benham, London, 1-87.

Azuma M, Cate CN (1971) Sixteen new species and one new genus of Japanese Ovulidae. The Veliger 13: 261-268.

Azuma M (1989) Systematic studies on the recent Japanese family Ovulidae (Gastropoda) XIV. Supplement (3) Description of a new species of the genus Crenavolva Cate, 1973. Venus 48: 161-166.

Cate CN (1973) A systematic revision of the recent cypraeid family Ovulidae. The Veliger suppl. 15: 1-116.

Coleman N (2003) 2002 Seashells: Catalogue of Indo Pacific Mollusca. Neville Coleman's Underwater Geographic Pty Ltd., Australia, 144 pp.

Cumming RL (1997) Ovulids (Gastropoda) associated with gorgonians (Anthozoa: Gorgonoidea) at Cape D’Aguilar, Hong Kong: species, hosts, distributions and feeding ecology. In: Morton B (Ed.) The Marine Flora and Fauna of Hong Kong and Southern China (IV). Proceedings of the eight International Marine Biological Workshop, Hong Kong, April 1995. Hong Kong University Press, Hong Kong, 285-301.

Fabricius KE, Alderslade P (2001) Soft corals and sea fans: A comprehensive guide to the tropical shallow water genera of the central-west Pacific, the Indian Ocean and the Red Sea. Australian Institute of Marine Science, Townsville, 264 pp. 
Fehse D (2002a) Contributions to the knowledge of Ovulidae (Mollusca: Gastropoda). XI. A new species of the genus Primovula Thiele, 1925. La Conchiglia 34: 36-40.

Fehse D (2002b) Contributions to the knowledge of Ovulidae (Mollusca: Gastropoda). X. The genus Crenavolva Cate, 1973. La Conchiglia 34: 23-55.

Fleming J (1822) The philosophy of zoology, or a general view of the structure, functions, and classification of animals. Hurst, Robinson \& Co, Edinburgh, 432 pp. doi: 10.1037/11823-000

Folmer O, Black M, Hoeh W, Lutz R, Vrijenhoek R (1994) DNA primers for amplification of mitochondrial cytochrome c oxidase subunit I from diverse metazoan invertebrates. Molecular Marine Biology and Biotechnology 3: 294-299.

Goh NGC, Ng PKL, Chou LM (1999) Notes on the shallow water gorgonian-associated fauna on coral reefs in Singapore. Bulletin of Marine Science 65: 259-282.

Gosliner TM, Behrens DW, Williams GC (1996) Coral reef animals of the Indo-Pacific. Sea Challengers, Monterey, 314 pp.

Hoeksema BW (2007) Delineation of the Indo-Malayan Centre of Maximum Marine Biodiversity: The Coral Triangle. In: Renema W (Ed.) Biogeography, Time and Place: Distributions, Barriers and Islands. Springer, Dordrecht, 117-178. doi: 10.1007/978-1-40206374-9_5

Katoh K, Kazutaka K, Kuma K, Toh H, Miyata T (2005) MAFFT version 5: improvement in accuracy of multiple sequence alignment. Nucleic Acids Research 33: 511-518. doi: 10.1093/nar/gki198

Kükenthal W, Gorzawsky H (1908) Japanische Gorgoniden. 1. Teil: Die Familien der Primnoiden, Muriceiden und Acanthogorgiiden. In: Doflein F (Ed.) Beitrage zur Naturgeschichte Ostasiens. Abhandlungen Mathematisch-Physikalischen Klasse der Königlich Bayerischen Akademie der Wissenschaften Supplement Bd. 1, München, 1-71.

Lorenz F, Fehse D (2009) The living Ovulidae, a manual of the families of allied cowries: Ovulidae, Pediculariidae and Eocypraeidae. Conchbooks, Hackenheim, 651 pp.

Mase K (1989) Taxonomic significance of color patterning of the soft body in the family Ovulidae - Descriptions of soft body of 26 species. Venus suppl. 1: 75-120.

Meyer CP (2003) Molecular systematics of cowries (Gastropoda: Cypraeidae) and diversification patterns in the tropics. Biological Journal of the Linnean Society 79: 401-459. doi: 10.1046/j.1095-8312.2003.00197.x

Palumbi SR (1996) PCR and molecular systematics. In: Hillis D, Moritz C, Mable B (Eds) Molecular Systematics. Sinauer Press, Sunderland, 205-247.

Penn O, Privman E, Ashkenazy H, Landan G, Graur D, Pupko T (2010) GUIDANCE: a web server for assessing alignment confidence scores. Nucleic Acids Research 38 (suppl 2): W23-W28. doi: 10.1093/nar/gkq443

Puillandre N, Lambert A, Brouillet S, Achaz G (2012) ABGD, Automatic Barcode Gap Discovery for primary species delimitation. Molecular Ecology 21(8): 1864-1877. doi: 10.1111/j.1365-294X.2011.05239.x

Reijnen BT (2010) Camouflage hampering the taxonomy of Ovulidae (Mollusca: Gastropoda) in the centre of marine biodiversity (Halmahera, Indonesia). Australian Shell News 137: 5-7.

Ronquist F, Huelsenbeck JP (2003) MRBAYES 3: Bayesian phylogenetic inference under mixed models. Bioinformatics 19: 1572-1574. doi: 10.1093/bioinformatics/btg180 
Rosenberg G (2014) Crenavolva Cate, 1973. Available from World Register of Marine Species at http://www.marinespecies.org/aphia.php?p=taxdetails\&id=204661 [accessed 26 November 2014]

Schiaparelli S, Barucca M, Olmo E, Boyer M, Canapa A (2005) Phylogenetic relationships within Ovulidae (Gastropoda: Cypraeoidea) based on molecular data from the 16S rRNA gene. Marine Biology 147: 411-420. doi: 10.1007/s00227-005-1566-0

Sowerby I GB (1828) On the recent species of the genus Ovulum. Zoological Journal 4: 145-162.

Sowerby III GB (1900) On some marine shells from Pondoland and the Kowie, with descriptions of seventeen new species. Proceedings of the Malacological Society of London 4: 1-7.

Stiasny G (1947) De gorgonarien-familie Acanthogorgiidae Kükenthal \& Gorzawsky, 1908 met bijzondere inachtneming van het materiaal der Siboga-expeditie. Verhandelingen der Koninklijke Nederlandsche Akademie der Wetenschap, Afd. Natuurkunde. Tweede Sectie 43: 1-93.

Tamura K, Stecher G, Peterson D, Filipski A, Kumar S (2013) MEGA6: Molecular Evolutionary Genetics Analysis Version 6.0. Molecular Biology and Evolution 30: 2725-2729. doi: $10.1093 / \mathrm{molbev} / \mathrm{mst} 197$

Yamamoto T (1973) Molluscs symbiotic with coelenterates in Japan, with special reference to Ovulidae and allied forms. Publications from the Seto Marine Biological Laboratory 20: 567-581. 